\title{
THE ENVIRONMENTAL CHALLENGES, PROBLEMS,AND MANAGEMENT: A CASE STUDY OF JORDAN
}

\author{
Ola Al Jaafreh', Imre Nagy² \\ Received: June 12, 2018 | Accepted: July 15, 2018
}

\begin{abstract}
The challenges of environmental protection is divided between various governmental institutions in Jordan such as Ministry of environment, Ministry of Irrigation, Ministry of Health, Ministry of municipalities affairs, In this study, the tasks of each ministry and its affiliated institutions were determined through the provisions of the constitution and the law in the Hashemite Kingdom of Jordan. The most important environmental problems were included with some studies and reports that dealt with these problems through scientific and statistical analysis.
\end{abstract}

Keywords: environment, Jordan, environmental institutions, air pollution, water pollution, soil pollution, landfill, waste management.

\section{INTRODUCTION}

Jordan has been the home of many civilizations (Jordan Tourism Board, 2006).Human settlements have been established there since the beginning of ancient history (Jordânia, 2017), location of Jordan is about 80 kilometers east of the Mediterranean Sea, between latitude $29^{\circ} 11^{\prime}$ to $33^{\circ} 22^{\prime}$ north, and longitude $34^{\circ} 19^{\prime}$ to $39^{\circ} 18^{\prime}$ east (Ministryof Environment, 2007). As a result of the great changes that are taking place in the world in particular in communications and technology in all fields in the middle of the last century, growing population threaten the environmental, economic, spiritual, aesthetic and cultural benefits currently being derived from living land resources(Basiago, 1999). The problem is exacerbated by the Kingdom of Jordan vulnerability to the political situation in the region and waves of displaced people that have led to an unusually large and surprising population increase. Next, the pressure on natural resources such as water and energy has increased significantly over the past decades(The Forty-Eighth Session of the UN Commission on Population and Development, 2015).

Faculty of Economic Sciences, Kaposvár University, Hungary, contact: ola.aljaafreh.ku@gmail.com

Faculty of Sciences, University of Novi Sad, Serbia 
The problems of the developing countries in general and Jordan are the physical problems and the lack of qualified expertise(ESCWA Technology Centre \& El Hassan Science City, 2012). It is important to mention the biggest enemies of the environment, even for a country like Jordan that has not been involved in any war so far. It is known that the environment does not recognize political borders. Such as air pollution not only affects the countries involved, but also neighboring countries. This article will address the environmental problems in the Jordanian Kingdom in general.

\section{INSTITUTIONAL FRAMEWORK TO MANAGE THE ENVIRONMENT IN JORDAN}

When assessing the institutional system of environment protection (and nature protection andwater management), we have to look at the responsibilities(competencies) and also the operational areas (areas of effect) of the special institutions of the "Jordan".

This study below is a summary of the evaluation of the institutional systems and the managementand official control of environment protection are institutionally separated. The former tasks are provided by the Environmental, Nature, and Water Directorates, while the latter is the responsibility of the Inspectorates for Environment, Nature, and Water, the Inspectorates exercise in the first degree the environmental, nature protection, landscape protection and water management competencies specified by law, the Inspectorate operates the laboratory necessary for the authority operation; it keeps registrations specified in separate acts; it collects the data related to its activity and makes them available for the National Environmental Information System; also, it cooperates with other control and information systems. The Directorate contributes to the preparation of the national and regional programmes for the purification and safe deposition of municipal sewage, and to the research, training, education and knowledge dissemination activity related to environmental protection. The Directorates in different countries are also responsible for keeping registrations specified by law, the operational areas of the Inspectorates and Directorates are unique among the examined countries.For example in Hungarythe Water Resources Research Centre (VITUKI) is a research company interested in environmental and water management issues further to the Ministry of the Environment And Water Management, their operational areas cover the administrative boundaries of municipalities that belong to different water catchment areas, also in Romania the National Institute for Research and Development in Environment is responsible for similar tasks with the Ministry of the Environment (Nagy et al. 2010).

The task of environmental protection in Jordan is divided between various governmental institutionssuch as the Ministry of Environment (MoEnv), Ministry of Health $(\mathrm{MoH})$, Ministry of Waterand Irrigation (MWI) and Ministry of Municipalities and the Municipalities itself; each of these institutions has articles in their respective laws (an overview is given in the section on national legislation) giving them the responsibility tomaintain and monitor some aspects of environmental quality(Nait, 2008).

MoEnv was established in Amman in January 2003, The MoEnv includes four main technical departments, which are: land use, environmental impact assessment, water 
quality and air quality monitoring, the reason to established this ministry that the attention to environmental issues and pressure on the environment were increased(Francis et al, 2008). The Ministry of the Environment was set up in 2003(UNDP, 2014), depend on the ratification of the Temporary Environment Protection Law no (1) of 2003 instead of the General Corporation for Environmental Protection (GCEP)/Ministry of Municipal Affairs, which was set up in 1996(TheWorld Bank, 2005), since 1996 and according to the former Environment Protection Law No.12/1995, the GCEP had been the major governmental agency responsible for environmental protection. The Ministry of Environment, being a new institution, has a limited number of staff (only 170 members), the Ministry's goalsare to maintain and improve the quality of Jordan's environment, conserve and protect natural resources and contribute to sustainable development through applying the effective policies, legislation, strategies, monitoring and by mainstreaming environmental concepts into all national development plans(UNDP, 2013).

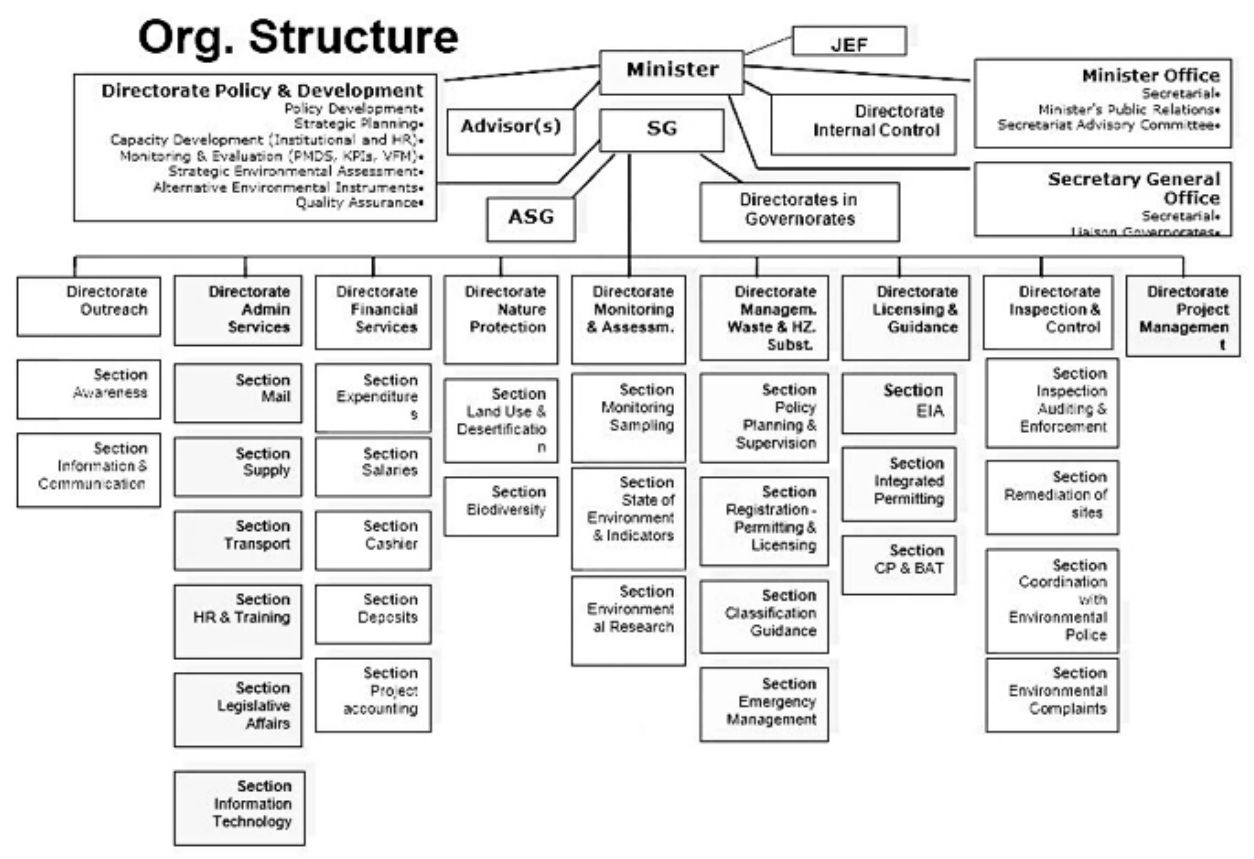

Figure 1. Ministry's organizational chart of 2011 with all the directorates.

Source: Nait, 2008

The Ministry of Health $(\mathrm{MOH})$, is responsible mainly for ensuring the drinking water safety and suitability, monitoring sewerage systems, and for ensuring public health(http://www.moh.gov.jo). All water and sewerage systems projects must comply with health standards and are subject to approval by $\mathrm{MOH}$, also the Ministry of Health which can provide water and wastewater quality data and data on air pollutants proposes and the ideal disposal methods for medical waste, Department of Statistics(DOS) provides data on quantity disposal methods for medical wastes. (DOS) was set up in late 
1949 and assumed its activities in accordance with the Statistics Law No. 24 for the year 1950, which identified its responsibilities and duties, directorates of( DOS ) are: Directorate of Agricultural and Environmental Statistics, Directorate of Economic Statistics, Directorate of Population and Social Statistics and Directorate of Household Surveys. The Environment Statistics department was established in 1995 and it covers most environmental issues and components. Department of Statistics produces data from annual environmental surveys and from administrative registrations of environmental relevant institutions in Jordan. It publishes an annual environmental statistics report, a compendium and annual environmental sustainable indicators, alsosome environmental indicators are calculated while other data are re-tabulated in the form of tables for inclusion in annual environmental statistics reports.

The Ministry of Water and Irrigation (MWI) with the Water Authority of Jordan (WAJ) and Jordan Valley Authority (JVA), three organizations are directly responsible for the water sector in Jordanandthe Minister of Water and Irrigation is the head of both organizations(http://www.mwi.gov.jo).

$\mathrm{WAJ}$ is responsible for conserving, developing, protecting and managing all water resources and sewerage projects, no official or local person or party is permitted to carry out any works related to water and sewerage of any nature, if these works are considered to be within the sole responsibility of WAJ under the respective law (WAJ Law No.181988) and the regulations issued in accordance with it, except after obtaining the Minister's written approval.

JVA is responsible for all activities within JVA boundaries including water, irrigation, construction work, etc. No ministry or government or semi-government agency is allowed to perform water and irrigation construction activities in the Jordan Valley without permission from the JVA except for operation and maintenance activities. Moreover, no person is allowed to establish in the Valley any private buildings or structures of any kind for any purpose before obtaining a license from the JVA.

Ministry of Municipal Affairs and the Municipalitiesand Joint Services Councils(JSCs) - Cooperation with the Ministry of Municipal Affairs is carried out through representatives of the Royal Directorate of Environmental ProtectionMunicipalities in the Hashemite Kingdom of Jordan and through participation in health and safety committees, accompanying the inspectors of the Environment Department to control violations of dumps, waste and defamation offensesSanding, accompany health department inspectors to detect shops in order to control health and safety violationsthe public, and follow up complaints received by the Ministry of Municipalities related to environmental violations(RDPE, 2014), Joint Services Councils have many duties related to ministry of municipalities affairs but in environmental sector it hasdirectresponsibility forWaste management at the regional level (Jordan GBC, 2016). 


\section{AIR POLLUTION}

There are no comprehensive studies to determine the quality of air in the Kingdom, but there are studies carried out in specific areas and for specific periods of time, because the problem of air pollution is a local problem confined to "hot areas" resulting from the movement of transport and industries and construction and the nature of the region geographically as a semi-dry desert Chemical pollutants in sulfur dioxide, carbon monoxide, particulate matter andLead bullets.

The recent study has been conducted to evaluate the vehicular emissions of hydrocarbons and carbon monoxide for gasoline-driven motor vehicles in the Greater Amman Area in order to provide the government with the main information necessary for developing and updating new vehicular exhaust emissions standards, it was found that the incompliance rates of CO and HC to limits specified in Traffic Law no. 14/1984 were $40 \%$ and $25 \%$ respectively, motor vehicles age was found to be the most important factor affecting vehicular emission levels, Old vehicles were found to have been caused by twice the amount of carbon dioxide and three times as much as that of new cars. In addition, public transport vehicles have been shown to contribute to higher carbon dioxide emissions than those for private cars. The total $\mathrm{CO} 2$ emissions in the country were estimated at around 5.18 million tons, $2.3 \%$ of which was attributed to the power sector (UNESCWA, 2001).

Zarqa is home to $52 \%$ of the Jordanian industries(Zarqa Municipality, 2016), emissionsand phosphate accumulation from local refineries are among the governorate's major environmental pollution problems. The area also is affected by emissions from the nearby thermal power plant, industrial wastewater, and the dust from brick and stone quarries (Farid b.Chaaban, n.d.).

According (Sana'a Abed El-Raoof Odat, 2009), thestudy aimed at using the statistical methods to assess air quality at Al-Hashimeya town in Zarqa Governorate, three main Al- Hashimeya are contributing to air pollution; Jordan Petroleum Refinery, Al-Hussein Thermal Power Station, and Assmrawastewater treatment plant. The study showed that Assamra Station was the main source of $\mathrm{H} 2 \mathrm{~S}$ ts concentration had exceeded the Jordanian standards throughout the monitoring months, the levels of TSP has shown that they exceeded the national standards with different degrees. Weather conditions (air Tem-

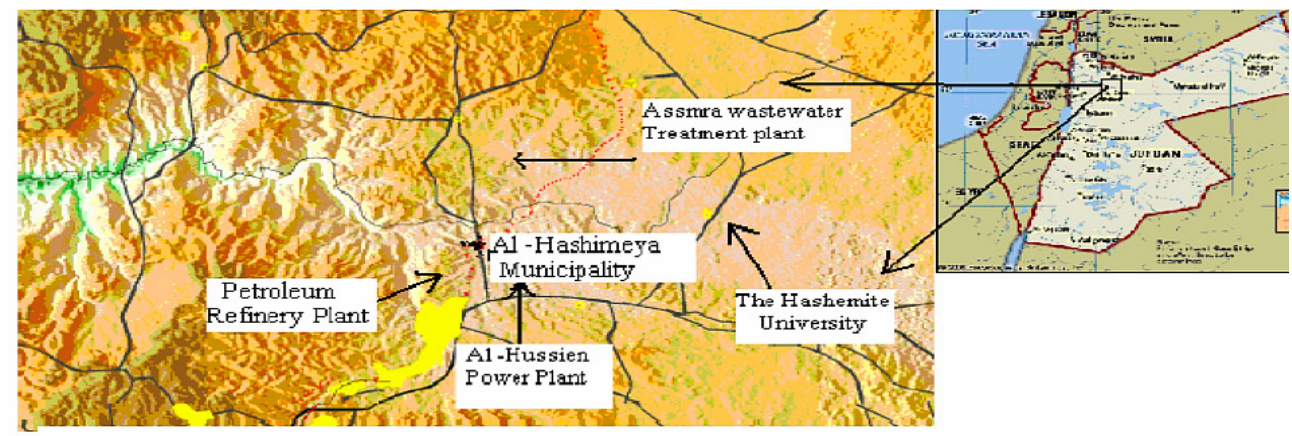

Figure 2. Location of Al- Hashimeya and the areas around 
perature, wind speed, rainfall, wind direction, cloud and relative humidity) have contributed to the high of air pollution.

In another statistical study; relationships between the concentrations of heavy metals in air and the average number of vehicles per hour at the various sampling sites, (a) $\mathrm{Cu}$; (b) $\mathrm{Zn}$; and (c) $\mathrm{Pb}$. Statistical analysis of the data in Table 1, shows significant differences ( $\mathrm{p}=0.05)$ between $\mathrm{Zn}$ and $\mathrm{Cu}(\mathrm{r}=0.82), \mathrm{Zn}$ and $\mathrm{Pb}(\mathrm{r}=0.96)$, and $\mathrm{Cu}$ with $\mathrm{Pb}(\mathrm{r}=0.73)$ at the different sampling areas. Also, the correlation coefficients between $\mathrm{Zn}, \mathrm{Cu}$, and $\mathrm{Pb}$ with a number of vehicles per hour $(\mathrm{r}=0.95,0.80$, and 0.96 respectively) suggest that these heavy metals come from the same source, namely automobile emissions(Jaradat \& Moman, 1999).

Table 1. The levels of $\mathrm{Cu}, \mathrm{Pb}$, and $\mathrm{Zn}\left(\mu \mathrm{g} / \mathrm{m}^{3}\right)$ in the air compared with other studies worldwide

\begin{tabular}{|l|c|c|c|}
\hline Place & $\mathrm{Cu}$ & $\mathrm{Pb}$ & $\mathrm{Zn}$ \\
\hline Amman & $0.26-0.6$ & $0.26-1.63$ & $0.12-0.38$ \\
\hline Taiwan & 0.17 & 0.78 & 1.56 \\
\hline Cairo & 0.19 & 0.01 & 0.09 \\
\hline Riyadah & $0.24-2.91$ & $0.20-4.09$ & $0.04-0.62$ \\
\hline Cairo & - & $0.6-3.0$ & - \\
\hline Chile & $0.02-0.22$ & - & $0.02-.026$ \\
\hline Black sea & - & & 0.051 \\
\hline Spain & $0.013-0.0082$ & $1.55-0.70$ & $0.047-0.022$ \\
\hline
\end{tabular}

Source: Jaradat and Momani, 1999

\section{WATER POLLUTION}

Jordan is one of the driest countries in the world (USAID, 2015), Jordan's main water resources consist of surface water resources and groundwater, with the use of increasingly treated wastewater, in irrigation, especially in the Jordan Valley(Nortcliff, Carr, Potter, \& Darmame, 2008), the sources of surface water running in the valleys are divided into floods caused by heavy rainfall, Primary runoff water from groundwater bodies and water discharged from wastewater treatment plants.

The scarcity of water in Jordan requires us to do our utmost to preserve, every drop of water, pollution is one of the main reasons for the reduced availability of usable water for different purposes, it works Jordan strives to protect its available water resources through implement water quality control programs and use their results in decision making required to protect these sources(Royal scientific society, n.d.).

The erosion of the soil from the water basins by rainwater and floods and their deposition in dam lakes, which reduces the storage capacity and short life and impact on the outlets of water at the bottom of the body of the dam, which threatens to close it like deposits in the Lake of the King Talal Dam, sediments work on the growth of algae and 
fungi in dam lakes that are consumed in its growth is dissolved oxygen in the water and causes unpleasant odors, unpleasant taste, and non-color it is desirable in water, as it works to block sunlight from deep water layers inLakes dams.

The excavations resulting from the construction of the Amman-Jerash Highway have had an impact on the rate increaseThe sediments in Lake Talal Dam reached in 1995 the height of which was it is supposed to arrive in 2005.

Deposits in the King Abdullah Canal reduce the amount of liquefied water and slow down the flow of the channel many of its hydraulic properties and the cost of maintenance and in some the situation leads to the cessation of pumping to the drinking water project Deir Ala Amman due to loads the dense mud of water from the canal during the flood season.

Since the 1980s, Jordan has attempted to expand the construction of most sewage networks cities and urban areas, linking homes and establishing purification plants to treat this water and in the valleys to be used for irrigation, the 17 water treatment plants were constructed, operated and maintained by the Ministry of Water and Irrigation another 11 private stations were established in the Kingdom.The following three systems are used to treat wastewater:

1. Natural purification plants (Ponds Stabilization Water Waste) include plantsKhirbet Samra, Aqaba, Madaba, Ramtha, Ma'an, Mafraq and Wadi Musa, these stations are characterized by low efficiency compared to mechanical purification stations where they ranged its efficiency in the removal of organic materials between $62 \%$ to $92 \%$ except Wadi Sir and which its efficiency increased to $93 \%$.

2. Stations of biological filters (Trickling Filter) - Stations Karak, Tafila, Kfrnga and Baqaa, these stations operate with a system of biological filters which are highly efficient in removing materials which ranged from $92 \%$ to $96 \%$.

The drainage of treated wastewater has affected the side valleys and dams, particularly King Talal Dam on the water quality of these valleys especially as they are mixed with flood and flood waters and storage in dam lakes, which made this water unfit for drinking and used in irrigated agriculture its quality is also subject to further degradation and pollution for the following reasons:

- Degraded efficiency due to the increased flow of water in quantities exceeding design capacity for purification plants.

- Linking many factories to sewage networks leading to an increase in organic loads in water.

- Drought and its impact on the quantities of fresh water and flood water contained in dam lakes This water decrease during the drought years, leading to a concentration of pollutants in water sewage treatment.

Communities that can't be connected to sewage networks because they are not available population to the establishment of cesspits for the pollution, esspits for the pollution, esspits for the disposal ofdomestic wastewater, this system is followed in most Jordanian cities and villages that lack sanitation projects, septic drilling doesn't arise according to correct engineering and hygienic methods and in most cases does not, their 
sides and floors are lined and often have access to waste water, which is often threatened, springs and groundwater pollution, and the cases in which the water of these pits led to contamination of drinking water rare and the control of drinking water and its sources prevent this happening.In the north, domestic wastewater is disposed of in cesspits emptying it into the Elkader landfill, which is a serious environmental and health problem unless it is addressed radically.

The Ministry of Water and Irrigation statistics for 1999 indicate that there are 153 industrial establishmentsJordan, of which 63 are connected to sewage networks and 90 are non-industrialConnected to these networks and pour out water in the streams of floods and valleys(Water Authority-Jordan Valley Authority, 2015)

In 1999, the rate of organic load of the factories connected to the drainage networks $(5788 \mathrm{~kg} /$ day) and the population allowance for organic pregnancy (105242) on the basis of the organic load of the individual $55 \mathrm{~g} /$ person/day, the factories are not the average organic load rate was $1,007 \mathrm{~kg} /$ day, equivalent to a population equivalent up to 20127 people and the largest rates of daily organic pregnancy come from slaughterhouseGreater Amman Municipality (50\% of the organic dream of connected factories on the net) and factoriesJordanian Yeast (38\% of the organic load rate of unincorporated plants. (Bani Hani, 2002).

The percentage of factories in violation of Jordanian specifications for industrial wastewater is 202 about $49 \%$, and the food industries, which accounted for $36 \%$, the most polluting factories are paper mills, iron, chemicals and chemical detergents and food industries.

The expansion of Jordan in the field of irrigated agriculture, which led to the occurrence of activities resulting from agriculture are important sources of water pollution and the negative impact on the environment and the most important:Use of treated wastewater in agriculture, Pesticides and fertilizers, Crop residues, Residues of livestock, Plastic residue, and High soil salinity due to evaporation of irrigation water and salt springs. Hydrological changes in water basing:

- Transferring the waters of the Jordan River into a salt watercourse.

- Construction of dams in water basins (Yarmouk, Zarqa, and others).

- Sewage of treated wastewater in the streams of surface water basins.

- Conversion of large or full percentage of current surface water discharges into channels or pipes for irrigation on lands outside the water basin, such as diverting the Yarmouk River to the King CanalAbdullah and turned it into the upper basin to irrigate the plains of Houran and the Golan on the Syrian side.

- Reduced Dead Sea water due to the diversion of water from the Jordan River and its fresh tributaries.During the 1950s it was about 1200-1600 million cubic meters of water reaching the Dead Sea freshwater annually and now up to the Dead Sea no more than 300 million cubic meters in the year, which led to the drought of the southern basin and the decline of the northern basin and the decrease of spaceDead Sea from 1000 square kilometers to less than 700 square kilometers and lower its water level is more than 18 meters over the past five decades(Bani Hani, 2002). 
Hydrological changes on water basins through the implementation of water projects have had a significant impact on water the quality of fresh water and the reduction in quantities available to Jordan in addition to the negative effect on vegetation and biodiversity and the imbalance of the environment in most of these neighborhoods which adversely affected the species of animals and plants that were endemic to these ponds and surroundings, other contaminants: oils and fats from car wash stations and mechanisms, residues of olive presses and Medical Waste. The impact of these pollutants on the water in Jordan remains unclear and studies are required about these topics(Bani Hani, 2002).

\section{DEFORESTATION}

Desertification is one of the most important environmental problems in Jordan, Jordan About $81 \%$ of the total area and the area threatened by desertification is about $16 \%$, the (MINISTRY OF ENVIRONMENT, 2006)Convention on Desertification (1994) defined desertification as degradation or degradationLands in dry, semi - dry and semi humid areas result from different factors among them climate differences and human activities, when we talk about desertification, we are talking about a process of environmental degradation in which environmental systems are lost survival and recovery of new and restored matrices where degradation of soil fertility and production the land is fading economically.In 1994, the International Convention to Combat Desertification was adopted 1996 was the first international treaty to address directly the environmental degradation in the regions rural areas.

The main causes of desertification in Jordan is poor land management in general and the absence of a system a clear policy for the management and allocation of land uses in a sustainable manner, the rest the human and natural causes of desertification are natural causes, climate plays an important role as it is more than $90 \%$ of the area of Jordan is located in areas with a rainfall below $200 \mathrm{~mm}$, in addition, the seasons of drought which occur from year to year contribute to the development of desertification conditions, Water, and air pollution, the erosion of soil is intended to remove the fertile layer of the container on organic and metallic materials, Plants and animals role in their interaction with their environment they contribute mainly to conservation on the balance or degradation of the environment, overgrazing leads to rapid removal of vegetation resulting in increased erosion.

Areas prone to desertification as defined by the National Strategy to Combat Desertification(1994)(MINISTRY OF ENVIRONMENT, 2006), there are four regions in Jordan mainly to the problems of desertification:

The first area is the desert areas with hot climates, including Jafar, Ma'an, Safawi and Ruwaished, the southern valleys, the Wadi Araba, the al-Qasba and the Disi areas, which are suffering from desertification in all its forms and manifestations, especially the absence of vegetation cover and saline soil land is the most desert in Jordan and desertification is accelerating in these areas due to lack rainfall (less than $100 \mathrm{~mm}$ per year). In the eastern border with Saudi Arabia are scattered dunes, Sand dunes in many 
areas and especially in Wadi Rum, Ghadir Shaikh, Bayer and Madhura, where the region lacks permanent vegetative vegetation, and the plants do not have the waterways of the watery valleys seasonal.

The second area is the this situation represents the areas located on the fringes of AlBadia as areas of Mafraq, Wadi Mafraq and Zarqa city which are subject to desertification due to wrong agricultural practices and highlight the most important the manifestations of desertification in them through the erosion of soil because of water and wind and overgrazing in addition to wrong agricultural practices. As for natural plants in this area they suffer from poor seed yield and poor nutrient content of the soil characteristics of calcareous. However, naturally protected sites in this area have proved capableHigh on productivity in the absence of human pressures and the ability to resist impactsEnvironment.

The third one including areas with a Mediterranean climate, including some semiarid and semi-arid regions, it has an average rainfall of between 300 and $600 \mathrm{~mm}$ per year, some areas of Amman, Irbid, Ramtha and Baka, which are subject to structural changes in the system as a result of urban encroachment, assault on vegetation and low productivity of soil, areas that are in a state of transition towards desertification and where the effects of desertification will extend not processed quickly. The manifestations and indicators of desertification in these areas are declining area of forest and a high proportion of water - induced drift and urban expansion the declining organic value of the soil and the deterioration of its food content and directed towards more hardness.

Fourth areas are the case of irrigated agriculture in the Jordan Valley and extend from Lake Tiberias north to the Dead Sea in the south (Ministry of Environment, 2006).

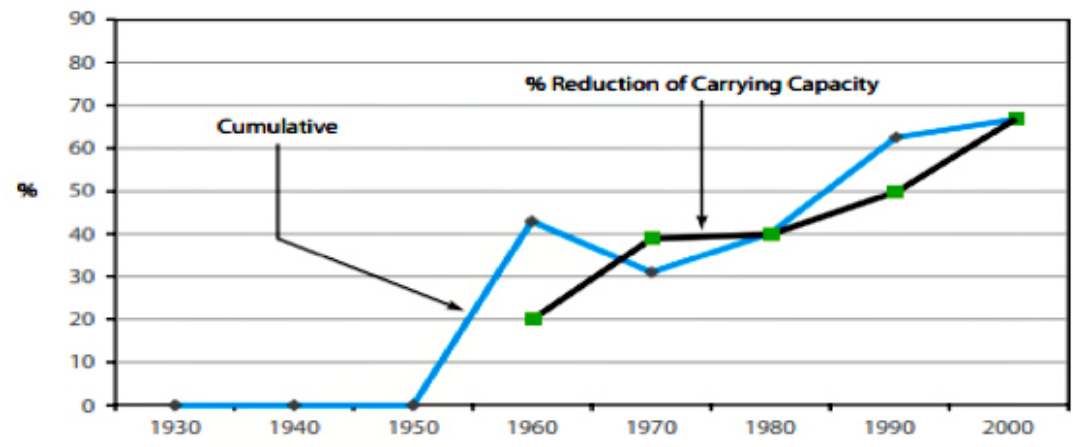

Figure 3. Percentage and the cumulative reduction in carrying capacity of rangelands in Jordan Source:Al Karadsheh, Akroush, \& Safa Mazahreh, 2012. 


\section{SOIL POLLUTION}

The most important soil pollution challenges in Jordan are the following: Pollution from pesticides, chemical fertilizers, and hormones, leading to changes in the soil characteristics and increasing the poisonous material that can affect human health. Pollution caused by plastics, wastewater and drainage water, increase in soil salinity in much of the Al-Ghour area, increased water consumption for other purposes at the expense of agricultural uses( Al-Zu'bi, 2007).

The agricultural units are divided into two parts depending on the type of water: the first section is irrigated with Yarmouk water and the second part is fed from the water of King Talal dam, where the soil samples were taken under the drip irrigation system from under the irrigation line directly and from the agricultural lines and among the plants and for surface irrigation samples were taken vertically And horizontally.

When samples were taken from the line of agriculture and irrigation and from the lines horizontally and vertically to different depths in the cultivated soils in vegetable crops and to a depth of $80 \mathrm{~cm}$ in the soils planted with fruit trees were also taken samples of land not previously cultivated lands adjacent to the agricultural trees that are irrigated from Yarmouk water and samples from the neighboring area, which is irrigated from the waters of King Talal Dam with a total of 486 samples, of which 324 samples, the total number of specimens was 486 samples, of which 324 samples were from vegetables, 144 were citrus, 18 were unedged, and chemical, physiological and microbiological analyzes were carried out.The study concluded that all analyzes of the soil samples mentioned did not have any heavy metal contamination. In all the samples obtained, no high limit was found for the permissible limits. This is a characteristic of the soil of the rivers where the heavy elements do not dissolve and if found they leak down and thus the possibility of absorbing them from The plant is unlikely to occur, it has also been shown that there is an increase in concentration of the major nutrients (nitrogen, potassium, phosphorus), which is caused by excessive fertilization of the farmers, which leads to salinity of the soil and low quality and reduce fertility, which reduces the economic revenue of this agricultural product.

\section{THE PROBLEM OF WASTE MANAGEMENT}

Waste generation, management and disposal is an extremely complex issue(Isenhour et al., n.d.), the solid waste management sector in Jordan is one of the most complex sectors(Schuler et al., 2008) due to presence wide sets of different types and combinations of solid waste, waste management, and landfill places are managed by 100 municipalities and 21 joint services councils in Jordan(European Commission, 2016).

Millions of tons of solid waste are produced in Jordan from agricultural sourcesMunicipal and industrial sectors annually(Momani \& Shawaqfah, 2013). The manufacturing process has led to an increase and rising population growth rates due to forced $\mathrm{mi}$ gration in the recent period have increased rapidly in the production of solid waste in Jordan, which has led to increased pressure on infrastructure existing waste manage- 
ment, In a study of the Alakidr waste dump, physical and chemical measurements were estimated within a $6 \mathrm{~km}$ area of the landfill site and included impacts on the direction of groundwater flow, The result of the study showed that the landfill posed a serious threat to local groundwater(Abu-Rukah \& Al-Kofahi, 2001)however, current solid waste management services within local municipalities are no longer at the same level which was before the large influx of refugees, and the daily rate of solid waste generation has increased significantly, which is generated daily in Irbid350 million tons of municipal solid waste and Al Mafraq, Which should be collected and transferred by the responsible municipalities to final disposal sites.

Landfills and disposals in Jordan are divided into three sections according to their regional location: northern regions has four landfills which areAlakidr landfill, Northern Jordan Valley, Al-Husainiyya and Northern Badia, Alkidar landfillis the largest waste disposal site in the north of the Kingdom, which is $35 \mathrm{~km}$ away east of the city of Irbid and $15 \mathrm{~km}$ east of Ramtha city, Alkidar dump currently serves 31 municipalities northern region, as follows: 18 in Irbid, 6 in Jerash, and 7 in Ajloun, the site is run byJoint Services Council of Irbid Governorate.On the other hand runs the JSCMafraq Governorate of Al - Husayniyat for disposalWaste, which is located $20 \mathrm{~km}$ eastRetail, Al Hossainat currently serves 10 municipalities in Mafraq Governorate, in addition to a campZatari for Syrian refugees located in Mafraq, all waste disposal sites in the north of the Kingdom are landfill sites and all of them suffer from a lack of equipment and infrastructure.

Five waste disposal sites operating in the central region, its include:Al-Ghabawi Landfill, the only sanitary landfill with a geometrical design in the Kingdom, Madaba landfill, Hamra, Deir Aal and Al-Daleel. Al-Ghabawi dump is the largest landfill, the first of its kind in Jordanbecause it was completed designed and built with a gas collection system with financial assistance from the World Bank, the site has been established in 2003 to include 9 landfills.Southern area it include also nine dumps operating in the southern region, six of them: Aqaba, Al-Qweira, Maan, Gorf ALDrawish, Al-Lajun and Ell, all of these sites don't the engineering method of landfill, Al Baraka, andAlsamer and the village of Muhammadiyah are using open / burning dumps with occasional coverage(Jordan GBC, 2016).Many studies have been conducted to evaluate the benefit from using the biogas production from landfills, one of these studies evaluated the total emission reduction from two landfills in Jordan in the lifespan (25 years) of the biogas plants will be about $1,406 \mathrm{Gg} \mathrm{CH} 4$. It will generate electricity at a cost of US $\$ 0.046$ per $\mathrm{kWh}$, which is less than the Jordan electric long-run marginal cost of generation at 5.5cents per $\mathrm{kWh}$. Furthermore, annual savings of US $\$ 4.65$ million will replacement of fuel oil with the generated biogas will achieveannual savings of US $\$ 4.65$ million. Also, studies concerning the energy production content of municipal solid waste in Jordan was conducted and it accounted for $6 \%$ of the annual imported oil consumption of the country and may result in an annual saving of US\$24 million in case of the utilization(Aljaradin, 2014). 
Table 2. Electrical energy production in Jordan (GWh) (Electricity 2010)

\begin{tabular}{|l|l|l|l|l|l|}
\hline \multirow{2}{*}{ Electricity Sector } & 20 & 200 & 2 & 2 & 2006 \\
\cline { 2 - 6 } & 84 & 913 & 1 & 1 & 18.4 \\
\hline Steam Units & 71 & 752 & 5 & 6 & 13.9 \\
\hline Gas Turbines /diesel & 46 & 341 & 6 & 3 & -52.2 \\
\hline Gas Turbines /natrual & 77 & 648 & 9 & 9 & -2.9 \\
\hline Diesel Engines/HFO & 1 & 2 & 4 & 1 & -75 \\
\hline Hydro Units & 53 & 57 & 5 & 6 & 19.6 \\
\hline Wind Energy & 3 & 3 & 3 & 3 & - \\
\hline Bio Gaz & 6 & 5 & 6 & 1 & 66.7 \\
\hline Combined Cycle & 0 & 558 & 3 & 5 & 31.8 \\
\hline Industrial Sector & 49 & 516 & 4 & 3 & -17.3 \\
\hline
\end{tabular}

Source: Aljaradin, 2014.

In table 2 the changing in electrical energy supply in Jordan for the years, 2004-2007 is presented, the growth rate in biogas production for electricity generation is large, but the proportion of the total electrical energy supply from an-fossil sources is small. The biogas contribution for producing electricity has increased slightly from 2004 to 2007. The biogas as a renewable source of energy is accepted in Jordan for producing clean renewable electricity; the increasing of producing energy in 2007 will promote the government to invest more in this sector, low level of awareness regarding the health and environmental impacts of improper management of solid waste makes recycling and disposal programs difficult to implement(Mrayyan \& Hamdi, 2006), furthermore number of companies are active in thewaste sorting within landfills (iron, aluminum, plastic, paper, cardboard and glass bottles)(Internationale Zusammenarbeit - GIZ, 2014). Most of the work done inside the landfill is done through scavengers employed by the private sector. Most of the landfills in Jordan are rented for private sector companies, for example, Alakidr landfill is rented with 60000 JD /year, Alhsinyat 40000 JD/ year, and Alhmra landfill with $20000 \mathrm{JD} /$ year. The waste recycling process depends mainly on the prices of the sorted materials as shown in table 3.

Table 3. The prices of some sorted materials

\begin{tabular}{|l|c|}
\hline Recycle & Price (JD/Ton) \\
\hline plastic & 300 \\
\hline Colorful & 200 \\
\hline A white & 350 \\
\hline Iron & 250 \\
\hline Aluminum & 110 \\
\hline Cardboard & 65 \\
\hline
\end{tabular}

Source: Aljaradin, 2014. 


\section{TOTAL ENVIRONMENTAL EXPENDITURE OF THE PUBLIC SECTOR OF GDP}

The largest government environmental expenditure was from the general budget at a rate of $70 \%$ during the period $2000-2007,30 \%$ of other sources such as external loans and grants for the same period.

Six environmental expenditure programs have been analyzed in six environmental protection and management activities directly linked to progress MDGs targets for the seventh Millennium Development Goals (MDGs), and show that the public sector environmental expenditure programshave been fully reflected on three out of six programs.

On the expenditure totals, government spending on the environment increased from 220 million dinars in 2000 to 306 Million dinars in 2007 at constant prices $(2000=100)$ How much was the proportion of government spending on the environment $7.3 \%$

Of GDP in 2007 and 1.8\% of total government expenditure(ESCWA, 2009).

Table 4. Total environmental expenditure of the public sector of GDP(2000-2007)

\begin{tabular}{|l|c|c|c|c|c|c|c|c|}
\hline $\begin{array}{l}\text { Economic indicators } \\
\text { of environmental } \\
\text { expenditures }\end{array}$ & 2000 & 2001 & 2002 & 2003 & 2004 & 2005 & 2006 & 2007 \\
\hline $\begin{array}{l}\text { Gross domestic product } \\
\text { at current prices (million } \\
\text { dinars) }\end{array}$ & $5,989.1$ & $6,181.3$ & $6,587.1$ & $6,841.3$ & $7,522.8$ & $7,845.2$ & $8,083.8$ & $8,230.7$ \\
\hline Inflation rate & 0.7 & 1.8 & 1.8 & 2.3 & 2.6 & 6.5 & 6.3 & 5.4 \\
\hline $\begin{array}{l}\text { Total government } \\
\text { expenditure (million } \\
\text { dinars) }\end{array}$ & $2,529.0$ & $2,636.6$ & $2,695.7$ & $3,075.0$ & $3,352.4$ & $3,497.2$ & $3,698.7$ & $3,794.7$ \\
\hline $\begin{array}{l}\text { Ratio of government } \\
\text { expenditure to GDP }\end{array}$ & 42.2 & 42.7 & 40.9 & 44.9 & 44.6 & 44.6 & 45.8 & 46.1 \\
\hline $\begin{array}{l}\text { Environmental Expenditure } \\
\text { (Million JD) }\end{array}$ & 219.9 & 249 & 230.4 & 226.8 & 232.8 & 245.9 & 283.4 & 306.1 \\
\hline $\begin{array}{l}\text { Percentage of } \\
\text { environmental expenditure } \\
\text { of GDP }\end{array}$ & $3.7 \%$ & $4 \%$ & $3.5 \%$ & $3.3 \%$ & $3.1 \%$ & $3.1 \%$ & $3.5 \%$ & $3.7 \%$ \\
\hline $\begin{array}{l}\text { Percentage of } \\
\text { environmental expenditure } \\
\text { from general government } \\
\text { expenditure }\end{array}$ & $8.7 \%$ & $9.4 \%$ & $8.5 \%$ & $7.4 \%$ & $6.9 \%$ & $7.0 \%$ & $7.7 \%$ & $8.1 \%$ \\
\hline
\end{tabular}

Source:(ESCWA, 2009) 


\section{DISCUSSION AND RESULTS}

The major finding of this study which also agrees with the others studies that Jordan faces environmental challenges due to limited resources, primarily water resources and high growth rates, the lack of adequate awareness at the individual and decision-making levels of the importance of making the decision more effective As a way to environmental management, and put the public in front of its responsibilities in dealing with the environment for improve the Sustainable development.

Environmental education, awareness, and communication are an essential element of environmental protection and conservation, Therefore, this study emphasizes the importance of these areas and the extent of their current capabilities, And to use their experiences in developing trends, values, and knowledge that will help achieve sustainable development.

\section{RECOMMENDATIONS}

Some of the proposed recommendations to increase the effectiveness of the measures taken to protect the environment in Jordan from pollution and according to the current situation are as follows:

1. Enhancing the role of the laboratories directorate in the Jordan Valley Authority to develop effective programs for monitoring the quality of irrigation water, soil, and plants in the Jordan Valley projects.

2. Activate the programs of water quality studies based on the financial resources of the self in addition to the grants and assistance of international bodies interested in water in Jordan and ensure the continuity of these programs and commensurate with the changes and developments in water resources and uses.

3. Increasing the number of branches of laboratories and quality control in the Kingdom's governorates and in water projects, where necessary and possible, in order to achieve decentralization and increase the efficiency of monitoring and analysis of all water sources and their uses for various purposes.

4. Monitoring the financial allocation of the crisis to develop manpower and raise the level of performance and provide them with the necessary tools and means to maintain the quality of water and protection from pollution and reduce the negative effects on the environment.

5. Increasing the control of factories regarding the taking of preventive measures to reduce and prevent environmental pollution.

6. Stimulate companies to participate in community initiatives to protect the environment to be focused not only on maximizing profit.

7. Supporting voluntary initiatives of non-governmental organizations to educate citizens on ways to conserve air, water, and soil in their environment and to define simple and effective ways to manage, reduce, recycle or even re-use wast 


\section{CONCLUSION}

Environmental problems are obstacles in the face of economic and social progress and human development in Jordan and anywhere in the world. Coordination between state institutions entrusted with working with the involvement of the private sector, including the implementation of many projects and initiatives and amending the provisions of the law and legislation in Jordan to help preserve and develop the Jordanian environment Emergency and renewable environmental problems with the conditions of the homeland and public policy.

\section{REFERENCES}

Abu-Rukah, Y., \& Al-Kofahi, O. (2001). The assessment of the effect of landfill leachate on ground-water quality-a case study. El-Akader landfill site—north Jordan. Journal of Arid Environments, 49(3), 615-630. https://doi.org/10.1006/JARE.2001.0796

Al Karadsheh, E., Akroush, S., \& Safa Mazahreh, E. (2012). Land Degradation in Jordan - Review of knowledge resources OASIS Country Report 1. Aleppo. Retrieved from http://pdf.usaid.gov/pdf_docs/PBAAF671.pdf

Aljaradin, M. (2014). Solid Waste Management in Jordan. International Journal of Academic Research in Business and Social Sciences, 4(11). https://doi.org/10.6007/IJARBSS/v4-i11/1289

Basiago, A. D. (1999). Economic, social, and environmental sustainability in development theory and urban planning practice. The Environmentalist. Retrieved from https://www.amherst.edu/system/files/media/0972/fulltext.pdf

ESCWA. (2009). Public Environmental Expenditures Case Study: Jordan. Retrieved from http://css.escwa.org.lb/sd/1097/Env_Exp_Jordan_Ar.pdf

ESCWA Technology Centre, \& El Hassan Science City. (2012). 2013 ECOSOC Annual Ministerial Review Regional preparatory meeting for Western Asia \&quot; Science, Technology and Innovation for Sustainable Development \&quot; BACKGROUND NOTE 1-Introduction: the role of STI for sustainable development in WANA region 3 2. Retrieved from http://www.un.org/en/ecosoc/newfunct/pdf13/amr-Jordan-background.note.pdf

EUROPEAN COMMISSION. (2016). Commission implementing decision. Retrieved from https://ec.europa.eu/neighbourhood-enlargement/sites/near/files/aap2016_ part_2_and_aap_2017_part_1_jordan.pdf

Farid b.Chaaban. (n.d.). Air Quality. Retrieved from http://www.afedonline.org/afedreport/english/book4.pdf

Francis, P., Thomas, L., \& Cohen-Gonzalez, J. (2008). JORDAN ENVIRONMENTAL FUND Guidelines for Establishing the Fund and Pilot Year Operations Final Report. Retrieved from http://pdf.usaid.gov/pdf_docs/Pnadm738.pdf

Internationale Zusammenarbeit (GIZ). (2014). COUNTRY REPORT ON THE SOLID WASTE MANAGEMENT IN The Regional Solid Waste Exchange of Information and Expertise network in Mashreq and Maghreb countries COUNTRY REPORT ON THE 
SOLID WASTE MANAGEMENT IN JORDAN. Retrieved from http://www.rangers. psd.gov.jo/sites/default/files/files/JORDANIE RA ANG WEB_0.pdf

Isenhour, C., Criner, G., Hart, D., Silka, L., Peckenham, J., Rock, C., ... Mitchell, G. J.

(n.d.). Solid Waste Management in Maine: Past, Present, and Future. Retrieved from https://umaine.edu/mitchellcenter/wp-content/uploads/sites/293/2015/02/FinalSolid-Waste-Whitepaper.pdf

Jaradat, Q. M., \& Moman, K. A. (1999). Contamination of Roadside Soil, Plants, and Air With Heavy Metals in Jordan, A Comparative Study. Turk J Chem, 23, 209-220. Retrieved from http://citeseerx.ist.psu.edu/viewdoc/download?doi=10.1.1.464.940\&rep $=$ rep1\&type $=$ pdf

Jordan GBC. (2016). Official Guide to Waste Management in Jordan. Retrieved from http://library.fes.de/pdf-files/bueros/amman/12728.pdf

Jordan Tourism Board. (2006). JORDAN'S HISTORY \&amp; CULTURE. Retrieved from http://pt.visitjordan.com/e_book/history_culture.pdf

Jordânia, G. da. (2017). About Jordan. Retrieved December 23, 2017, from http://www. just.edu.jo/cesare17/Documents/About Jordan.pdf

Ministry of Environment. (2006). National Strategy and Plan of Action to Combat Desertification. Amman. Retrieved from http://moenv.test.jo/AR/EnvImpactAssessmentStudies/Documents/Final Arabic_NAP_070905 pdf.pdf

MINISTRY OF ENVIRONMENT. (2006). NATIONAL STRATEGY AND ACTION PLAN TO COMBAT DESERTIFICATION. Retrieved from http://cmsdata.iucn.org/ downloads/jordan___nap.pdf

MINISTRY OF ENVIRONMENT. (2007). THE HASHEMITE KINGDOM OF JORDAN. Retrieved from http://www.moenv.gov.jo/en/envimpactassessmentstudies/ documents/jordan-eng.pdf

Mohammad Bani Hani. (2002). Sources of water pollution in Jordan and efforts to combat it. Amman. Retrieved from http://www.alraicenter.com/User_Site/Site/images/ stories/pdf/water.pdf

Momani, F. A. Al, \& Shawaqfah, M. (2013). Agricultural Solids Waste in South of Jordan: Facts and Figures. Journal of Environmental Protection, 4, 309-314. https://doi. org/10.4236/jep.2013.44036

Mrayyan, B., \& Hamdi, M. R. (2006). Management approaches to integrated solid waste in industrialized zones in Jordan: A case of Zarqa City. Waste Management, 26(2), 195-205. https://doi.org/10.1016/J.WASMAN.2005.06.008

Nagy I, Belanka Cs, Duray B , Hardi T, Mezei I., Pánovics A Duray B , Mezei I, Nagy I , Pánovics A (szerk.) Environmental Policy and the Institutional System of Environment Protection in the Carpathian Basin, Pécs: Centre for Regional Studies of the Hungarian Academy of Sciences, 2010. 38 p. (Discussion Papers; 79. ) (ISBN:978963-9899-28-5)

Nait, S. (2008). Towards a Shared Environmental Information System (SEIS). Copenhagen. https://doi.org/citeulike-article-id:11530353

Northcliff, S., Carr, G., Potter, R. B., \& Darmame, K. (2008). Jordan's Water Resources: Challenges for the Future. Retrieved from http://www.reading.ac.uk/web/files/geographyandenvironmentalscience/GP185.pdf 
RDPE. (2014). Environmental security in Jordan. Amman. Retrieved from http://www. rangers.psd.gov.jo/sites/default/files/files/ندرالا يف بئيبلالنمال/.pdf

Royal scientific society. (n.d.). Environment Monitoring and Research Central Unit (EMARCU). Retrieved from http://css.escwa.org.lb/ICTD/1441/2-2A.pdf

Sana'a Abed El-Raoof Odat. (2009). Diurnal and Seasonal Variation of Air Pollution at Al. JEES, 2(1). Retrieved from http://www.jjees.hu.edu.jo/files/v2n1/1.pdf

Schuler, N., Casalis, A., Debomy, S., Johnnides, C., Kuper, K., Cointreau, S., ... Baeumler, A. (2008). WHAT A WASTE A Global Review of Solid Waste Management. Goicoechea. Retrieved from http://www.ifc.org/wps/wcm/connect/1e5ca7004c07698db5 8eb7d8bd2c3114/What-A-Waste-Report.pdf?MOD=AJPERES

The Forty-Eighth Session of the U.N Commission on Population and Development. (2015). The Position of the Hashemite Kingdom of Jordan (p. 7). New York. Retrieved from http://www.un.org/en/development/desa/population/pdf/commission/2015/ country/Agenda item 4/Jordan_EN_Item4.pdf

THE WORLD BANK. (2005). tTHE HASHEMITE KINGDOM OF JORDAN General JOINT VENTURE OF COTECNO WITH ABT ALCHEMIA CDG MGA COTECNO ABT ALCHEMIA CDG MGA GENERAL -ANNEX B -ANALYSIS OF THE MUNICIPAL SECTOR 23-04-05 PAGE 2 OF 73. Retrieved from http://www.mota. gov.jo/Documents/Municipal_sector.pdf

U N D P. (2013). Jordan Poverty Reduction Strategy Final Report Retrieved from http:// www.jo.undp.org/content/dam/jordan/docs/Poverty/Jordanpovertyreductionstrategy.pdf

UNDP. (2014). Jordan's Third NationalCommunication on Climate Change The UnitedNations Framework Convention on Climate Change (unFCCC). Retrieved from http://unfccc.int/resource/docs/natc/jornc3.pdf

USAID. (2015). Jordan Country Development Cooperation Strategy. Retrieved from https://www.usaid.gov/sites/default/files/documents/1883/Amended-Jordan-CountryDevelopment-Strategy-March-2015.pdf

Water Authority-Jordan Valley Authority. (2015). Ministry of Water and Irrigation. Retrieved from http://www.mwi.gov.jo/sites/en-us/Annual Reports/Report water-2015. pdf

Zarqa Municipality. (2016). Phase 1 of Planning for Local Economic Development: Municipal Strengthening Action Plan and Investment Opportunities Zarqa Municipality. USAID. Retrieved from http://jordanlens.org/sites/default/files/Zarqa LED PLAN Final_En_WEB.pdf 